Int. J. Electrochem. Sci., 15 (2020) 4567 - 4585

International Journal of

ELECTROCHEMICAL

SCIENCE

$\underline{\text { WWW.electrochemsci.org }}$

\title{
Treatment of Biotreated Coking Wastewater by a Heterogeneous Electro-Fenton Process Using a Novel Fe/Activated Carbon/Ni Composite Cathode
}

\author{
Yanqiu Wang ${ }^{1,2}$, Xinyu Zhou ${ }^{1}$, Nan Jiang ${ }^{1,3}$, Guangcai Meng ${ }^{1}$, Jinfeng Bai ${ }^{1,2, *}$, Yanli LV $V^{1,2}$ \\ ${ }^{1}$ School of Chemical Engineering, University of Science and Technology Liaoning, Anshan 114051, \\ P.R. China \\ ${ }^{2}$ Engineering Research Center of Advanced Coal \& Coking Technology and Efficient Utilization of \\ Coal Resources, the Education Department of Liaoning Province, Anshan 114051, P.R. China \\ ${ }^{3}$ Grinm Semiconductor Materials Co., Ltd., Beijing 100088, P.R. China \\ *E-mail: baijf863@126.com
}

doi: $10.20964 / 2020.05 .70$

Received: 29 January 2020 / Accepted: 7 March 2020 / Published: 10 April 2020

\begin{abstract}
A novel composite electrode was successfully developed that consisted of an activated carbonsupported iron salt and foamed nickel as the electrode material. Heterogeneous electro-Fenton (HEF) technology was applied to treat the biotreated coking wastewater (BTCW) with the electrode performing as the cathode. A response surface methodology combined with a single factor discussion was used to investigate individual parameters and the interaction of the three main parameters, namely, the applied voltage, plate spacing and initial $\mathrm{pH}$; the removal rate of the COD from the BTCW was selected as the response index. The results demonstrated that the plate spacing was the most influential parameter under the selected conditions. The optimized conditions, which were based on a BoxBehnken design (BBD), were as follows: applied voltage: $10 \mathrm{~V}$, plate spacing: $1 \mathrm{~cm}$, and initial $\mathrm{pH}$ : 3.42. Under these conditions, the COD removal efficiency could reach almost $100 \%$ after reacting for $3 \mathrm{~h}$. A spectroscopic analysis showed that the process could effectively remove aromatic protein analogs, microbial byproduct analogs, lactones and amide compounds in the coking wastewater. In addition, repetitive experiments indicated that the prepared electrode demonstrated good reusability. Therefore, the application of the novel composite electrode in the HEF process shows promising prospects for degrading organic contaminates in wastewater.
\end{abstract}

Keywords: Activated carbon; BBD; Biotreated coking wastewater; Heterogeneous electro-Fenton; Response surface methodology

\section{$\underline{\text { FULL TEXT }}$}


(C) 2020 The Authors. Published by ESG (www.electrochemsci.org). This article is an open access article distributed under the terms and conditions of the Creative Commons Attribution license (http://creativecommons.org/licenses/by/4.0/). 